\title{
般的信頼と信頼性判断
}

\author{
北海道大学 小杉素子²・山岸俊男
}

\section{General trust and judgments of trustworthiness}

Motoko Kosugi and Toshio Yamagishi (Department of Behavioral Science, Faculty of Letters, Hokkaido University, N10 W7 Kita-ku, Sapporo 060-0810)

Contrary to the common sense idea that trustful people are gullible and easily believe whatever other people may say, past research reviewed by Rotter (1980a) indicated the idea was not necessarily valid. Two experiments of this paper further demonstrated that trustful people are more sensitive to information that indicates lack of trustworthiness in other people. In the experiments, subjects read a series of stories in which a person was about to make a choice between a trustworthy action and an untrustworthy one. Some of them were also given pieces of information regarding trustworthiness of the person. They were then asked to predict the likelihood of the person taking a trustworthy action. When no information was given, high trusters predicted with higher probability than low trusters that the person would take a trustworthy action. On the other hand, the high trusters lowered the predicted likelihood more steeply than the low when negative information was provided.

Key words: trust, gullibility, person perception, judgment of trustworthiness.

\section{信頼と騙されやすさ}

信頼は人々が社会生活を営む上で重要な役割を果た している。そして，その重要性を反映するかたちで， 信頼に関する多くの研究がこれまでに行われている. それらの研究の中でも，信頼と騙されやすさの関係は 重要な問題の一つとして扱われてきた。たとえば社会 的学習の文脈や，社会的知能やスキルの文脈では，経 験により個人のもつ信頼や騙されやすさが適応的に変 化していく過程に焦点を当てた研究が行われている. その一つとして, 認知構造の複雑さと信頼, および対 人距離の近さに関する Garskeによる一連の研究があ る. Garske（1975）は，低信頼者は高信頼者に比べ 対人認知において複雑な認知方略を採ることを示し た。彼はこの結果を，低信頼者は物事を悪い方に考え 用心する傾向があるためどのような相手に対しても複 雑な認知方略を採るのに対し，高信頼者は物事を良い 方に考える傾向があり，疎遠で好意的でない人に対し

\footnotetext{
本研究は文部省科学研究費の助成を受けて行われた。

2 本研究に対し貴重なコメントをいただいた, 北海道大学の 篠塚寛美先生, 龟田達也先生, 林直保子氏, 神信人氏（現淑徳 大学）に感謝いたします。また，実験参加者の募集に際して， 福地保馬，森谷潔，方波見雅夫，三谷鉄夫，羽田野正隆，関孝 敏, 鹿野又伸夫，小井土彰宏，南弘征他の諸先生にご協力をい ただきました。ここに記して感謝いたします。
}

てのみ複雑な認知方略を採ると解釈した。したがって 用心深い低信頼者よりもそうでない高信頼者の方が騙 されやすいと示唆している.この点をより明らかに示 すために, Garske (1976) は信頼の高さと, 16PF テ スト（Cattel，1973）で測定した16の人格特性因子得 点との相関分析を行った。 その結果は，信頼と知能の 低さ，思考の単純さとが関係していることを示唆して おり，高信頼者が物事を単純に考える傾向があるとす る先述の結果と一貫している。また, Gurtman \& Lion（1982）は，用心深い低信頼者 ${ }^{3}$ が，信頼性の欠 如を示唆する刺激を選択的に知覚することを示す実験 を行った。実験では，3 種類の人格を表す形容詞（信 頼に値する・值しない・中立）を瞬間露出器を用いて 被験者に提示し，その形容詞を認知するまでの時間を 測定した。その結果，高信頼者よりも低信頼者の方が 信頼性の欠如を示唆する形容詞に対する反応が速く, ネガティブな刺激語を選択的に知覚する傾向の強いこ とが示唆された。この結果から彼らは，他者の信頼性 欠如に対して敏感な低信頼者の方が，そのような敏感 さに欠ける高信頼者よりも騙されにくいだろうと考察 している。また，Brann \& Foddy (1988) は社会的ジ レンマ状況を扱った研究で, 高信頼者の方が低信頼者

Gurtman \& Lion（1982）では，低信頼者は同時に用心深い と考えられている. 
よりも，非協力者の多くいる集団に留まる傾向が強い ことを報告し，この結果から，高信頼者は騙されやす いわけではないという Rotter（1980a）の知見に疑問 を投げかけている。

以上の研究とは逆の, 高信頼者が必ずしも騙されや すいわけではないことを報告している研究としては, まず，Rotterによる一連の研究があげられる。 Rotter （1967）は，信頼を“他者の言葉や約束，口頭ないし 書面による言明があてにできるという信念（p. 652)” と定義し，他者一般に対する信頼を測定するた めの対人信頼尺度（ITS）を開発した。この尺度を用 いた一連の研究を概観し，Rotter（1980a）は，信頼 と騙されやすさの間には関係がないと結論している. また Rotter（1971）は，ITS で測定された信頼とソシ オグラムや他の人格特性検査で得られた性格特性との 比較研究を検討し, 高信頼者は周りの人久からナイー ブで単純なお人好しだとはみなされておらず，実際に 低信頼者よりも騙されやすいわけではないとしてい る。またGurtman (1992) は, ITSやKanter \& Mirvis（1989）によるシニシズム尺度, Christie \& Geis（1970）によるマキャベリズム尺度等の, 信頼に 関連する尺度間の関係を検討し，低信頼者の方がむし ろ対人関係上の困難や苦痛を感じているのに対し, 高 信頼者にはそのような問題が少なく，また騙された経 験が低信頼者よりも多いわけではないことを明らかに している。

\section{信念としての信頼と情報に基づいた信頼}

なぜ，信頼と騙されやすさの関係に関して，このよ うな相反する結果が得られているのだろうか？この 疑問に答えるにあたつては, Rotter（1980a）による 信頼の定義が参考になる．Rotter は信頼を，疑うべき 明確な理由がない場合に相手を信じるかどうかとして 定義している。これは逆にいえば, 高信頼者は疑うべ き証拠がある場合にも相手を信じてしまうわけではな いことを意味している．疑うべき証拠がない限り相手 を信じる人間であっても，相手が信頼できない人間で ある証拠を無視するとは限らない.ここでの信頼と は, 他者一般の信頼性についての期待であり, 相手に ついての情報がない場合の相手の信頼性に対する “デ フォルト推定值”（山岸，1998）である. 特定の相手 を想定せず，人間一般に対する信頼に関する質問項目 から構成されている信頼尺度—Stack（1978）, ITS (Rotter, 1967), 人間性尺度 (Wrightsman, 1964), 信 頼尺度（Yamagishi，1986）など—が測定している のも，この意味での一般的信頼であるといえる.

また，Rotter（1980a，1980b）は，信頼を長期間の 社会的学習により形成される比較的安定した人格特性 として考えているが，この傾向の強い人が必ずしも一
えは，相手に関する情報がない場合の相手の信頼性に 対する期待としての信頼と，具体的な情報がある場合 にその情報を手がかりに行う相手の信頼性の評定と が，必ずしも同じでないことを示唆している．Rotter （1980a，b）によれば，騙されやすさはむしろ後者の 場合，つまり信頼性欠如情報があるにもかかわらずそ の相手を信頼するかどうかに直接関連しており，その ような情報がない場合に相手を最初から疑ってかかる かどうかとは直接関係していない. 同様の, 情報がな い場合の一般的な期待としての信頼と情報に基づいた 信頼との概念的区別は，山岸らの一連の信頼研究 (Yamagishi \& Yamagishi, 1994; 山岸・小見山, 1995）においても明確にされている.

高信頼者が騙されやすいとする先述の研究では, 相 手の信頼性に関する情報がある場合とない場合との区 別がなされていない。これらの研究では, Rotterの ITS により被験者の（疑うべき証拠がない限り相手を 信じる傾向としての）信頼の水準を測定していなが ら，疑うべき証拠がある場合にも高信頼者は相手を信 じてしまう，すなわち高信頼者は信頼性に関する情報 に注意を払わないで相手を過度に信頼すると仮定して いる。

\section{信頼と人を見る目}

以上の議論から，“低信頼者よりも高信頼者の方が 騙されやすいのか”という問題を設定する際には，信 念としての信頼と情報に基づいた信頼とを明確に区別 する必要がある。この区別を考慮した上で信頼と騙さ れやすさの関係を調べた研究としては菊地・渡邊・山 岸（1997）がある.この研究では, 未知の被験者同士 にお互いの情報を得る短時間の機会を与えたところ， 高信頼者の方が他者の信頼性を正確に評定することが 示された。この実験では，まず，未知の被験者同士を 6 人集団で, 30 分間討議させる. 被験者には集団討議 の実験であると教示するが，この討議の本当の目的 は，未知の被験者同士がお互いについて何らかの情報 を得ることにある. 討議終了後, もう一つ別の実験を 行うという名目で, 集団内の自分を除く 5 人の中から だれか 2 人と 1 回限りの 2 者囚人のジレンマ (PD) ゲームを行わせる. 被験者はPD の相手が集団内のだ れであるかわからない状態で “協力”と“非協力”の 選択を行う. 被験者は協力か非協力かを決定した後, 2 人の相手を知らされ，その 2 人のそれぞれがどちら の手を選んだかを予測する。この実験では, 相手 2 人 に対するそれぞれの行動予測がどの程度当たっていた かを他者の信頼性評定の正確さの指標とした（協力と 予測した相手が実際に協力, または非協力と予測した 相手が実際に非協力していた場合を, 正確な予測とす る)。その結果, 一般的信頼尺度で測定された高信頼 者の方が，低信頼者よりも相手の手を正確に予測して 
いた。この結果は，高信頼者は低信頼者に比べ，対人 関係の中で入手可能な情報を，他者の信頼性の評定に 積極的に用いる傾向をより強くもっていることを示唆 するものである。

\section{目 的}

菊地他（1997）の実験では，高信頼者の方が他者の 信頼性を正確に評定していたが，それが実際にどのよ うな過程をへて起こったのかは明らかでない。そこで 本研究は，低信頼者と高信頼者とで情報に対する反応 がどのように異なるかを明らかにすることを目的とし ている。具体的には，他者の信頼性を評定する際に手 がかりとなる情報を操作し, 高信頼者と低信頼者と で，情報に基づいた信頼性の評定，およびその変化の 仕方がどのように異なっているかを検討する。

また本研究では, 騙されやすさを, 不適切な情報処 理の結果として他者を誤って信頼してしまうことであ ると考える。したがってここで特に重要となってくる のは，他者の信頼性情報の処理ではなく，他者の信頼 性の欠如を示唆する情報の処理である。他者の信頼性 情報を適切に処理できない場合には，信頼に值する他 者を信頼しないという結果が生じるだけであり，そこ ではその個人は機会コストを支払うが，他者に騙され てひどい目にあうのは避けられる。しかし，他者の信 頼性欠如情報を適切に処理できず，誤って信頼に值し ない他者を信頼してしまうと，騙されてひどい目にあ う可能性が大きい。以上の考えに基づき, 本研究で は, 他者の信頼性欠如情報に対する反応に特に焦点を 当てた分析を行う。

\section{実 験 $\mathbb{1}$}

一般的信頼の高い人間は騙されやすいという主張 は，高信頼者が情報の有無にかかわらず常に相手の信 頼性を過剩評定するという前提に基づいている。これ に対して，一般的信頼の高さが必ずしも騙されやすさ を意味しないという主張は，特定の相手の信頼性を示 唆する情報に対して，少なくとも高信頼者も低信頼者 と同程度には敏感であるという前提に基づいている。 本研究では, 高信頼者と低信頼者とに特定の相手の信 頼性（ないしその欠如）を示唆する情報を与え，その 情報に応じた相手の信頼性の評定の変化を比較するこ とで，上述の二つの前提のいずれがより妥当であるか を明らかにする。具体的には，場面想定法質問紙を用 いて, 登場人物の行動がその人物の信頼性により影響 を受けると考光られる場面を想定させ，登場人物の信 頼性（ないしその欠如）を示唆する別の情報を提示し た後，登場人物のとる行動を予測させた。実験を行う 前に，刺激として用いる場面と情報を選定するため に，二つの予備実験を行った。本実験は 1995 年 6 月 初旬一7月初旬にかけて実施された。

\section{被験者}

北海道大学学生 257 人, 北海道酪農学園大学学生 57 人が実験に参加した。酪農大学学生は，授業時間 中に受講者全員が一斉に実験に参加した。北海道大学 学生は，本実験とは全く無関係な他の実験に参加した 被験者に実験参加を要請し, 承諾した学生が個別に実 験に参加した。

\section{手続き}

被験者は実験用冊子を配布され，表紙の一般的な説 明を読むように求められた。この説明では，冊子の中 の 15 場面のそれぞれにおいて登場人物がとると思わ れる行動を子測するようにとの教示がなされた。次 に，15 場面について登場人物の行動予測を行い，そ の後, 冊子の最後で 16 項目の信頼尺度に回答するよ う求められた。実験の実施には，全体で 10 分から 30 分程度の時間を要した。

実験用冊子には，予備実験で選ばれた 15 場面が含 まれている。予備実験では，登場人物がだれにも知ら れずに相手の信頼を裏切る行動をとりうる 38 場面を 被験者 141 名に提示し，登場人物がそのような利己的 行動をとるか，信頼に值する行動をとるかを予想さ せ，またその予想の確信度を評定させた。本実験のた めに，登場人物のとると予想された行動がいずれかの 方向に偏る程度の少ない 15 場面が選ばれた。Figure 1 は被験者に提示された場面の1例である。Figure 1 には, 別の予備実験で選出された, 登場人物の信頼性 欠如を示唆する情報も同時に提示されている。この子 備実験では，信頼性を示唆するポジティブ情報 23 , 信頼性欠如を示唆するネガティブ情報 23 を別の被験 者 141 名に提示し，対象者の信頼性を推測するのに役 立つ程度を評定させ，その程度が中程度（ある程度役 に立つが決定的ではない) で，かつすべての被験者に とって同程度の意味をもつとみなしうる情報を五つず

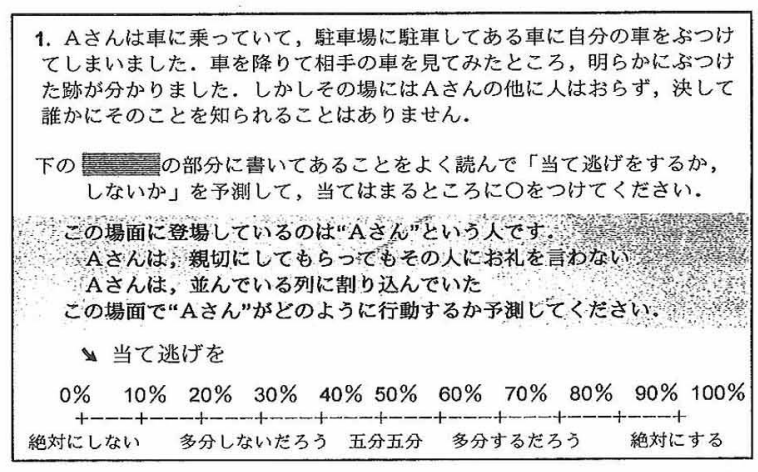

Figure 1. The response format of the questionnaire, with an example of judgment material that included two pieces of negative information. 
つ選んだ。

質問紙の構成 実験用冊子には，Figure 1 に示した のと同様な 15 場面が提示されている.場面は全被験 者に対して同じ順序で提示された。付加される情報に は五つの条件（情報なし 5 場面，ポジティブ情報 1 個 3 場面, 2 個 2 場面，ネガティブ情報 1 個 3 場面, 2 個 2 場面）があり，これら 5 条件のいずれがどの場面 に配置されるかは被験者ごとにランダムに決定され た。またそれぞれの場面に配置された情報条件に対応 して，どの情報が単独，あるいは組合せで何回用いら れるかも被験者ごとにランダムに決定された。たとえ ば Figure 1 の“当て逃げ”場面ではネガティブ情報 2 個が付加されているが，別の被験者に提示された冊子 では，この場面に別の情報がランダムに与えられてい た(たとえば “道端のごみを拾っていた”)。この方法 により, 情報 5 条件が被験者内要因として操作され た。また，情報内容と情報条件をランダムに場面に配 置することで，情報条件（ネガティブ情報 2 個など） と情報内容（“陰で人の悪口を言っていた”など）と 場面との交絡の影響が回避されている。登場人物の行 動予測の部分では，その状況で登場人物がとりうる二 つの行動（信頼に值する行動と利已的行動）が線分の 両端に示され $(0 \%=$ 利己的行動を絶対にする一 $100 \%$ ＝信頼に值する行動を絶対にする), 被験者は登場人 物の行動予測を, 線分上の当てはまる位置に○をつけ て示すよう求められた。被験者は 15 場面について登 場人物の行動を予測した後, 実験用冊子の最後の部分 で，一連の山岸らの信頼研究 (Yamagishi \& Yamagishi, 1994）で開発・改訂された信頼尺度に回 答した.

\section{要因配置}

実験デザインでは情報条件が被験者内要因として用 いられた。具体的には，登場人物の信頼性の評定值を 情報条件ごとに個人内で平均し，この值を被験者内要 因である情報条件に対する被験者の反応值として用い た

\section{結 果}

信頼尺度 信頼尺度は 16 項目からなっているが, 本研究では，他者一般の信頼性に対する信念としての 信頼を測定するための 6 項目からなる一般的信頼下位 尺度のみを用いた . 以下の分析に用いた一般的信頼 下位尺度 6 項目の信頼性はかなり高く $(\alpha=.81)$, 主

4 本研究では, 場面間の差は理論的な意味をもって扔らず, したがって同一情報条件に含まれる複数の場面の平均が分析に 用いられた。同じ情報条件に割りふられた場面は被験者ごとに ランダムに異なっているため, 場面の効果は被験者間のエラー 項に含まれることになる.
成分分析の結果も (寄与率 .60) 1 次元性を保持して いたので，その平均得点を被験者の一般的信頼の水準 の指標として用いることにした．以下の分析で高信頼 者と低信頼者に二分した分析がなされる場合には，被 験者の一般的信頼得点の中央値 $(3.33 \text { 点 })^{6}$ 用いた (高信頼 151 名, 低信頼 160 名 [有効回答者数 311]).

情報なし条件における信頼性の評定 本研究で用い られている一般的信頼とはRotter (1980a) や Yamagishi \& Yamagishi（1994）の定義による信頼, つまり他者一般の信頼性に対する期待であり，登場人 物の信頼性に関する情報が提示されていない場面で は，低信頼者よりも高信頼者の方が，登場人物が信頼 に值する行動をとると予測する傾向が強いはずであ る。この予測を検証するため，情報なし条件での登場 人物の行動予測の分析を行った。その結果, 被験者の 一般的信頼得点と登場人物の行動予測との間に，有意 な相関関係が見いだされた $(r=.17, p<.01)$ 。これら の結果は, 本研究で用いられた一般的信頼尺度が, Rotter (1980a) やYamagishi \& Yamagishi (1994) らによる理論的な定義の内容と一貫するものであるこ とを示している.

情報の効果 次に, 登場人物の行動予測の情報条件 ごとの平均值を従属変数に, ポジティブ情報とネガテ イブ情報のそれぞれについて, 情報数 $(0 \cdot 1 \cdot 2) \times$ 一 般的信頼（高・低）の 2 元配置の分散分析を行った (情報数は被験者内要因, 一般的信頼は被験者間要 因). Figure 2 に示されているように，登場人物の行 動予測に対する “ポジティブ情報”の数が多い方が $(F(2,618)=166.05, p<.01)$, また高信頼者の方が $(F(1,309)=5.96, p<.05)$, 登場人物が信頼に值する 行動をとると予測していた。また，ポジティブ情報の 数と一般的信頼との交互作用効果については, 情報の 数が多く，かつ一般的信頼の高い方が，登場人物が信 頼に值する行動をとると予測する方向を示していた

\footnotetext{
5 残り 10 項目は, 対人関係における慎重さの必要性について の信念を測定する用心深さ下位尺度を構成している.これら二 つの下位尺度の間の関係については, 清成・山岸 (1995), Yamagishi (1995), 山岸・小見山 (1995), Yamagishi \& Yamagishi（1994）などを参照されたい．この信頼尺度は 5 件法 であり，一般的信頼下位尺度に関しては，点数の高い方がより 他者を信頼する傾向にあることを意味する。一般的信頼尺度の 項目は“ほとんどの人は信用できる”“たいていの人は，人から 信頼された場合，同じょうにその相手を信頼する”“ほとんどの 人は他人を信頼している”“ほとんどの人は基本的に正直であ る”“私は，人を信頼するほうである”“ほとんどの人は基本的 に善良で親切である”の6 項目である.

6 一般的信頼尺度 $(M=3.36, S D=.83)$, 用心尺度 $(M=3.14$, $S D=.71)$. 一般的信頼尺度と用心尺度の相関 $(r=-.63, p<$ $.001)$.
} 
が，有意ではなかった $(F(2,618)=2.16, n s)$. 登場 人物の行動予測に対する “ネガティブ情報”の数の主 効果 $(F(2,618)=227.04, p<.01)$ は有意であった ——ネガティブ情報の数が多くなるほど登場人物が信 頼に值する行動をとる可能性を低く見積もつていた ——゙，一般的信頼の主効果は有意ではなかった $(F(1,309)=.02, n s)$. 情報数と一般的信頼との交互 作用効果については，ネガティブ情報に接すると，低 信頼者よりも高信頼者の方が登場人物に対する信頼を より急速に低下させる傾向がみられた $(F(2,618)=$ $3.60, p<.05)$. 特に, ネガティブ情報 2 個条件では, 低信頼者よりも高信頼者の方が登場人物の信頼性をよ り低く見積もる傾向さえみられている（ただし，この 条件での行動予測の差は有意ではない $[t(309)=1.50$, $n s])$.上述の結果のうち特に重要なのは，ネガティ ブ情報が与えられた際の一般的信頼と情報との交互作 用である。この交互作用は, 高信頼者の方が低信頼者 よりも特定の他者の信頼性欠如情報に敏感に反応する 傾向のあることを示しており，信頼感の高い人間は騙 されやすいとする Garske（1976）や Gurtman \& Lion (1982）らの主張に反するものだからである。さらに, この交互作用は，一方では信念としての信頼と情報に 基づいた信頼とを概念的に区別すべきであるとする Rotter (1980a) や Yamagishi \& Yamagishi (1994) の議論を支持しながら，これまでの彼らの議論からは 予測できなかった結果でもある.この交互作用の解釈 は総合考察で行うが，その前に，この交互作用の確認

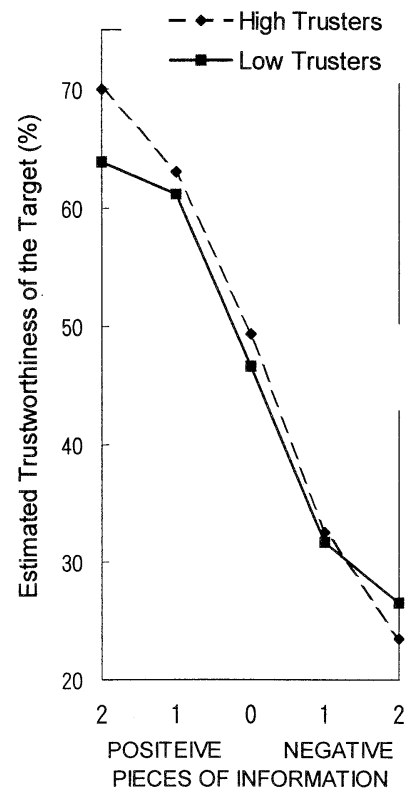

Figure 2. Estimated trustworthiness of the target as a function of general trust and the amount of positive or negative information in Experiment 1.
のために実施された追試実験（実験 2）の結果につい て報告する。

\section{実 験 2}

実験 2 の目的は，実験 1 で得られた情報数と一般的 信頼との交互作用効果の追試が可能であることを確認 することにある。したがって細部を除き，実験の手続 きは実験 1 とほぼ同じである。実験は 1995 年 10 月中 旬から 11 月中旬にかけて実施された。

\section{被験者}

北海道大学学生 75 名が実験に参加した。そのうち の 49 名は, 講義の一環として講義中に受講者全員が 一斉に実験に参加した。残りの 26 名は，本実験とは 全く無関係な他の実験に参加した被験者に実験参加を 要請し，承諾した学生が個別に実験に参加した。

\section{実験 1 からの変更点}

ポジティブ情報，ネガティブ情報ともに，3 個の情 報を提示する条件を加えた（使用した情報は実験 1 と 同じ 10 個である)。この情報条件の変更にともない, 場面も 16 場面に増やした（予備実験のデー夕をもと に同じ基準を用いて 1 場面増やした)。二つ目の変更 点は，情報なし条件を 2 種類設定した点にある. 1 種 類目の条件は実験 1 と同じ，特定の $\mathrm{A}$ さんについて 情報がない“特定相手情報なし条件”である。この条 件では，“この場面に登場しているのは Aさんという

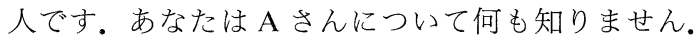
この場面で Aさんがどのように行動するか予測して ください”との教示がなされた。新たに追加された “不特定相手情報なし条件”では，“このような場面に 直面した“世間一般の人’はどうすると思いますか”と の教示がなされた。この条件の追加は, 特定の理論的 背景に基づいたものではなく探索的な目的のために行 われたものなので，次に報告する実験 1 の追試結果の 分析に際しては，実験 1 と共通の “特定相手情報なし 条件”のみを用いた。実験 1 にお抢ると同様の方法に より，八つの情報条件が 16 の場面に被験者ごとにラ ンダムに配置され（1 条件につき 2 場面)，また特定 のどの情報が何回どの情報条件に割り振られるかも被 験者ごとにランダムに決定された。また実験 1 におけ ると同様, 信頼尺度が冊子の最後に加えられている。 有効回答数は 72 であった 7 .

\section{結 果}

信頼尺度 ${ }^{8}$ 実験 1 亿扔けると同じ方法で内的一貫

7 男女比は 58：14であった。性差については，それぞれの情 報条件の評定值においても, 評定值の変化のパターンにおいて も，一貫して有意な差は得られなかった。 
性が確認された同 6 項目の尺度 $(\alpha=.83)$ により, 被 験者の一般的信頼の水準を測定した。実験 1 における と同様, 以下の分析では被験者の一般的信頼得点を中 央値（3.33 点）で 2 分割して（高信頼 36 名, 低信頼 36 名）用いた。

情報なし条件 ${ }^{9}$ における信頼性の評定 実験 1 にお ける情報なし条件と対応する特定相手情報なし条件に 抢ける登場人物の行動予測と一般的信頼得点の間の相 関はプラスであったが，有意ではなかった $(r=0.10$, $n s)$.

情報の効果 Figure 3 亿示された実験 2 の結果は, Figure 2 に示された実験 1 の結果とほぼ対応してい る. 実験 1 の結果が再現できるかどうかを調べるため に，まず，情報 3 個条件を除き情報数 $(0 \cdot 1 \cdot 2) \times 一$ 般的信頼（高・低）の 2 元配置の分散分析を行った. “ポジティブ情報”が与えられた場合の登場人物の行 動予測の変化に関しては, 情報数の主効果は再現され たが $(F(2,138)=16.71, p<.01)$ ，実験 1 において有 意であった一般的信頼の主効果は, 実験 2 においては

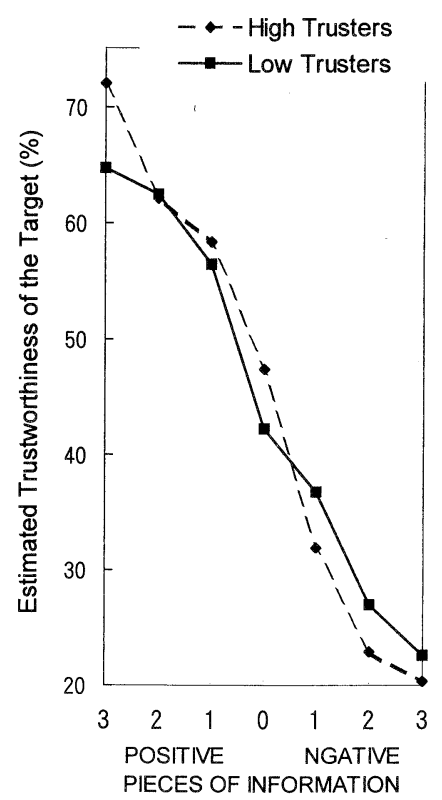

Figure 3. Estimated trustworthiness of the target as a function of general trust and the amount of positive or negative information in Experiment 2.

8 一般的信頼尺度 $(M=3.50, S D=.70)$, 用心尺度 $(M=3.20$, $S D=.68)$ 。一般的信頼尺度と用心尺度の相関 $(r=-.57, p<$ $.001)$.

9 不特定相手情報なし条件での分析結果も同様であった。評 定値のパターンは, 低信頼群 $(44.81, S D=16.21)$, 高信頼群 $(49.51, S D=15.99)$ で, 一般的信頼が高い被験者の方が, 登場 人物の行動をより信頼できると評定する傾向が強かった。 ただ し，この差は有意ではなかった $(t(70)=1.24, n s)$.
有意水準に達しなかった $(F(1,69)=.58, n s)$.また 情報数と一般的信頼との交互作用効果は, 実験 1 亿㧍 けると同様，有意とはならなかった $(F(2,138)=.57$, $n s)$ 。“ネガティブ情報”が与えられた場合には，実 験 1 におけると同様, 提示されるネガティブ情報の数 が増えるにしたがい登場人物の信頼性の評定が低まる ことが示された（情報数の主効果: $F(2,138)=9.2, p$ $<.01)$.また，一般的信頼の主効果は有意とはならな かった $(F(1,69)=.17, n s)$. 最後に, 情報数と一般 的信頼との交互作用効果は，実験 1 と同じ方向——ネ ガティブ情報に接すると，低信頼者よりも高信頼者の 方が登場人物に対する信頼をより急速に低下させる傾 向——を示していたものの，5\%レベルの有意水準に は達しなかった $(F(2,138)=2.94, p<.06)$. 次に, 情 報の数を三つに増やして同じ分析を行ったところ，結 果はほとんど同じであった ${ }^{10}$.

\section{総合考察}

実験の結果は，高信頼者が騙されやすいお人好しだ とする Garske (1975，1976) や Gurtman \& Lion (1982）らの予測，およびそれに対立する，一般的信 頼と騙されやすさとは独立だとする Rotter（1967）や Yamagishi \& Yamagishi (1994) の予測のいずれとも 反するものであり, 高信頼者の方が低信頼者よりも他 者の信頼性, 特にその欠如を示す情報に敏感であると いうものであった。この予想に反した，しかも一貫し た結果の解釈に際しては，まず以下の諸点に注意して おく必要がある。

まず，この結果が，場面想定法を用いた実験によっ て得られた点がある。場面想定法の結果からは，被験 者の心的過程がどの程度実験者の意図どおりに，また 現実状況として場面内容をとらえていたかが明らかで はないうえ，被験者が現実場面で必ず同様に反応する 保証はない. しかし, 本研究の知見が想像上の場面を 超えた現実の行動にまで反映している可能性は垣内・ 山岸（1997）の研究により示唆されている.PDを用 いたこの研究では, 協力的な相手と非協力的な相手に 対する高信頼者と低信頼者の対応を検討している。結 果は，低信頼者よりも高信頼者の方が相手の行動によ り敏感に反応していること，また，低信頼者は非協力

\footnotetext{
10 ポジティプ情報が与えられた場合には，情報の数の主効果は 有意であり $(F(3,207)=30.74, p<.01)$, 一般的信頼の主効果 $(F(1,69)=2.16, n s)$ も情報の数と一般的信頼の交互作用効果 $(F(3,207)=0.97, n s)$ も有意とはなっていない. またネガティ ブ情報が与えられた場合には, 情報の数の主効果は有意であり $(F(3,207)=37.4, p<.01)$, 一般的信頼の主効果は有意ではない $(F(1,69)=0.31, n s)$. 情報の数と一般的信頼の交互作用効果は, 上述の分析に扔けると同様，5\%レベルの有意水準には達してい なかったものの $(F(3,207)=2.09, p<.10)$, 実験 1 で示された のと同じ方向を示していた。
} 
的な相手を避ける行動を適切に取れなかったため相手 に㝛取され，そのため，実験後半になり相手が協力的 になった後でも，協力的な相手との関係をも避けよう とするようになることを示している。このように，行 動を指標とした垣内・山岸（1997）の実験からも低信 頼者よりも高信頼者の方が他者の信頼性欠如情報に敏 感であることが示されており，本研究の結果が必ずし も場面想定法を用いた場合のみに得られるものでない ことがわかる。

本研究の結果の解釈をめぐる第二の問題点は, 低信 頼者よりも高信頼者の方が，“信頼性欠如情報に対し て敏感である”というより，むしろ（実験者によって 提供された）“情報をそのまま鵜吞みにする傾向が強 い”ことを示しているのだと，全く逆の方向での解釈 を与えることができる点である。しかし，この点に関 しても，上述の垣内・山岸（1997）や菊地他（1997） の研究とあわせて考えれば，前者の解釈がより妥当で あると結論することができるだろう。

また，考慮しなければならない第三の点は，本研究 で用いた一般的信頼尺度が，高信頼者よりも低信頼者 の方が他者の信頼性欠如情報に敏感だとする Gurtman \& Lion（1982）の研究で用いられたITS と 異なっている点である。これまでの研究では, ITS が，他者の誠実さに対する信念と，他人とのつき合い で用心をする必要があるとする信念の，少なくとも2 因子を含んでいることが知られている(Chun \& Campbell, 1974; Kaplan, 1973). 同様の 2 因子は, ITS の項目を採り入れる形で作成された山岸の信頼尺 度（Yamagishi，1988）についても繰り返し報告され ている. 本研究はこれら 2 因子のうちの, 他者の誠実 さに対する信念因子に対応する一般的信頼因子のみを 用いている。これは, 本研究の目的が, 他者一般の信 頼性に対する期待としての一般的信頼と騙されやすさ との関係を明らかにすることにあったからである。こ れに対してGurtman \& Lion（1982）の研究では，こ れら 2 因子が区別されていない.この点を考えれば, 彼らの結果と本研究の結果との差異は, 次のような可 能性によりもたらされた可能性がある。すなわち, 高 信頼者は低信頼者よりも他者の信頼性欠如情報に敏感 であると同時に，用心深い人間は用心深くない人間よ りもそのような情報に敏感であるという可能性であ る.この解釈の妥当性を検討するために，一般的信頼 尺度の分析に扔けると同様，被験者を用心深さ尺度の 中央値で 2 分割し, 用心深い被験者群と用心深くない 被験者群との間に，情報の効果に差が存在するかどう かを検討した。用心深さメネガティブ情報の分散分析 の結果, 実験 $1(F(2,618)=.82, n s)$, 実験 $2(F(2$, $138)=.65, n s)$ ともに，有意な交互作用効果は得られ なかった。次に，一般的信頼の主効果を統制して共分 散分析を行ったが，同様に，実験 $1(F(2,616)=.20$, $n s)$, 実験 $2(F(2,136)=.01, n s)$ ともに，用心深さ ×ネガティブ情報の有意な交互作用効果は得られなか った。これらの結果から，信頼性情報に対する敏感さ と結びつくのは用心深さではなく一般的信頼であるこ とが示され，本実験の結果とGurtman \& Lion （1982）の結果との違いを説明するための, 用心深さ と一般的信頼とが情報に対する敏感さに対して逆方向 の関係にあるとする，上述の可能性は否定されてい る.

Gurtman \& Lion（1982）との違いの解釈に扔いて 注意すべき第二の点は, 彼らの実験では, 他者の信頼 性欠如を示す刺激語への反応時間を他者の信頼性欠如 情報に対する敏感さの指標としたのに対して, 本研究 では，対象の信頼性が直接表れやすいと思われる事態 での行動予測を指標とした点である.この違いの意味 についての一つの解釈は, Gurtman \& Lion (1982) が測定しているのは他者一般の信頼性の欠如に関する 信念の強さであり, 特定の他者の信頼性欠如情報に対 する敏感さではないという可能性である。つまり，低 信頼者は，他人は一般に信頼できないとする自分の信 念と一致する単語を認識しやすいだけであり，そのよ うな情報を実際に特定の他者の信頼性の判断に用いて いるのではないという可能性である。ただし，本実験 においてはこの解釈の妥当性を検討するために必要な 材料が提供されておらず，したがってこの解釈につい ては, 今後の研究を待つ必要がある。

上述のように, 先行研究の Gurtman \& Lion （1982）の結果との不一致をめぐる解釈に曖昧な点は 残ってはいるが，本研究の結果は，少なくとも以下の 点を示している。すなわち，人間一般の信頼性に対す る信念としての一般的信頼を高い水準で維持している 人間は，特定の人間の信頼性欠如情報に気づかなかっ たり，そのような情報を軽視したりするわけではな い.このことは，一般的信頼のレベルと，他者の信頼 性欠如情報に対する敏感さとの間に，直接の対応が存 在しないことを意味している。また，信頼と騙されや すさの関係については，情報に基づいた登場人物の信 頼性の評定が適切であるかどうかを検討するための材 料がないため, 本研究の結果のみからは十分に検討す ることができないが，上述の菊地他（1997）の結果を 援用することで，議論を進めることができる。他者に 関する情報があれば，高信頼者は低信頼者よりも，情 報を手がかりとして他者の信頼性に関する行動を正確 に予測できることはすでに示されている。そこで一つ の解釈として, 他者の行動を予測する場合, 信頼に值 する他者を捜すのではなく，むしろ信頼に值しない他 者を識別しているのではないかと考えられる，この説 明は，菊地他（1997）やYamagishi \& Kakiuchi （1997）における, 疑う理由がない限りは疑ってかか らない高信頼者の方が，最初からだれかれかまわず疑 
ってかかる低信頼者よりも，疑う理由を与える情報に 敏感であることを示す結果とも一貫している。これら 結果は, 本研究の結果も含め, これまでの信頼につい ての理論からは予測されて扔らず，また常識に反する ように思われるが，山岸（Yamagishi，1995，1996；山 岸，1996，1998）が示唆しているように，十分に解釈 可能であり，重要な理論的意味をもつものである。

山岸（1998）は，本論文で報告された実験を含む一 連の実験結果に基づき，低信頼者が “人を見れば泥棒 と思う”傾向が強いのは, “泥棒”と“誠実な人”と を見分けるために必要な，他者の信頼性欠如情報に対 する敏感さを身につけていないからだとする解釈を提 出している。他者の信頼性欠如情報に対して敏感でな い人は, 騙されないための予防措置として, 最初から “知らない人は信用できない”と決めつけておく必要 がある。逆にそのような情報に敏感な人にとっては， “疑う理由がない限りは決めつけない”態度を維持す ることが容易である。このような人は, 小さな手がか りから相手の信頼性欠如に気づくことができるため, 本当に危険な目にあう前に適切な手を打てる可能性が 高いからである。つまり, 注意深い慎重な人こそが他 者一般を信頼することができるのだとする逆説的な関 係を想定することができる。この解釈は信頼と騙され やすさとの関係についての新たな視点を提供するもの であり，その妥当性の検証のためには，新たな，より 詳細な研究が必要とされる。たとえば今後の研究にお いては，他者の信頼性欠如に対する敏感さを測定する 尺度を作成するなどして, 用心深さと他者の信頼性に 対する注意深さとの関係をより詳細に検討する必要が あるだろう。

\section{引用文献}

Brann, P., \& Foddy, M. 1988 Trust and the consumption of a deteriorating common resource. Journal of Conflict Resolution, 31, 615-630.

Cattel, R. B., 1973 Personality pinned down. Psychology Today, 7, 40-46.

Christie, R., \& Geis, F. 1970 Studies in Machiavelianism, San Diego, CA: Academic Press.

Chun, K., \& Campbell, J. B. 1974 Dimensionality of the Rotter Interpersonal Trust Scale. Psychological Reports, 35, 1059-1070.

Garske, J. P. 1975 Interpersonal trust and construct complexity for positively and negatively evaluated persons. Personality and Social Psychology Bulletin, 1, 616-619.

Garske, J.P. 1976 Personality and generalized expectancies for interpersonal trust. Psychological Reports, 39, 649-650.

Gurtman, M. B. 1992 Trust, distrust, and interper-
Personality and Social Psychology, 62, 989-1002.

Gurtman, M. B., \& Lion, C. 1982 Interpersonal trust and perceptual vigilance for trustworthiness descriptors. Journal of research in personality, 16, $108-117$.

垣内理希・山岸俊男 1997 一般的信頼と依存度選択 型囚人のジレンマ 社会心理学研究, 12, 212-226.

Kanter, D. L., \& Mirvis, P. H. 1989 The Cynical Americans: Living and working in an age of discontent and disillusion. San Francisco: Jossey-Bass.

Kaplan, R. M. 1973 Components of trust: Note on use of Rotter's scale. Psychological Reports, 33, 1314.

菊地雅子・渡邊席子・山岸俊男 1997 他者の信頼性 判断の正確さと一般的信頼一実験研究 実験社会心 理学研究, 37, 23-36.

清成透子・山岸俊男 1995 コミットメント形成によ る部外者に対する信頼の低下 実験社会心理学研 究, 36, 56-67.

Rotter, J. 1967 A new scale for the measurement of interpersonal trust. Journal of Personality, 35, 651665.

Rotter, J. 1971 Generalized expectancies for interpersonal trust. American Psychologist, 26, 443-452.

Rotter, J. 1980a Interpersonal trust, trustworthiness, and gullibility. American Psychologist, 35, 1-7.

Rotter, J. 1980b Trust and gullibility. Psychology Today, 102, 35-42.

Stack, L. 1978 Trust. In H. London \& J. Exner (Eds.), Dimensions of personality. New York: Wiley. Pp. 561-599.

Wrightsman, L. 1964 Measurement of philosophies of human nature. Psychological Reports, 14, 743-751.

Yamagishi, T. 1986 The provision of a sanctioning system as a public good. Journal of Personality and Social Psychology, 51, 110-116.

Yamagishi, T. 1988 The provision of a sanctioning system in the United States and Japan. Social Psychology Quarterly, 51, 265-271.

Yamagishi, T. 1995 Trust as cognition, trust as reflection. Paper presented at the Second Workshop on Construction and Maintenance of Trust. Seattle, September 9-10.

Yamagishi, T. 1996 Ingroup bias and culture of collectivism. Paper presented at the 50th Anniversary Conference of the Korean Psychological Association. Seoul, June 27-29.

山岸俊男 1996 認知資本としての信頼 第 21 回数 理社会学会大会研究報告要旨集, 60-63.

山岸俊男 1998 信頼一進化ゲームと開かれた社会 の基盤一 東京大学出版会.

Yamagishi, T., \& Kakiuchi, R. 1997 It takes venturing into a tiger's cave to steal a baby tiger: Experiments on the development of trust relationships. Paper presented at the Conference on The management of Durable Relations: Theoretical and Empiri- 
cal Models for Households and Organizations. Utrecht, June 26-28.

山岸俊男・小見山尚 1995 信頼の意味と構造：信頼 とコミットメント形成に関する理論的・実証的研 究. Journal of Institute of Nuclear Safety System, 2, 1-59.
Yamagishi, T., \& Yamagishi, M. 1994 Trust and commitment in the United States and Japan. Motivation and Emotion, 18, 129-166.

- 1996. 5.23 受稿, 1998. 3.14 受理一 